\title{
Significant Leadership Qualities for Saudi Arabia Construction Leaders
}

\author{
Ismail Abdul Rahman ${ }^{1}$ and Nashwan Al-Emad ${ }^{1, *}$ \\ ${ }^{1}$ Department of Building and Construction Engineering, Faculty of Civil and Environmental \\ Engineering, Universiti Tun Hussein Onn Malaysia, 86400 Parit Raja, Batu Pahat, Johor, Malaysia.
}

\begin{abstract}
Construction industry involves diverse individuals and organizations which are all targeted to achieve a specific task within a specific time. It really needs strong leadership quality of construction leaders in managing construction projects successfully. Hence, this paper presents a study to uncover leadership qualities which should be possessed by construction leaders to ensure the success of the construction project. A survey was designed based on literature review and also the outcomes of qualitative exploratory study. It was conducted using a semi-structured questionnaire distributed amongst selected construction experts in Makkah, Saudi Arabia. The selected experts should have more than 10 years' working experience in Saudi Arabia construction industry. The survey managed to collect 31 valid responses. The collected data was analysed using Average Index (AI) method to rank the qualities based on the significant level of each of the leadership quality. It was found that 10 most significant leadership qualities required by construction leaders are self-confident, problem solving skills, willingness to take responsibility, honest and trustworthy, respectful with subordinates, sufficient experience, integrity, effective management skills, continuous quality improvement and reliable with subordinates. These identified significant leadership qualities should be considered by construction stakeholders in hiring new employees or retraining their existing workers for Saudi Arabia construction industry.
\end{abstract}

\section{Introduction}

Construction industry requires a quality construction project management teams specifically in terms of leadership context. Based on Ofori \& Toor [1], leadership is an important aspect in all fields of human endeavour and more essential for the construction industry. Leadership can be defined as a process of influencing individuals or groups to accomplish an organizational goal or mission [2]. In construction industry, leadership means leading project team and managing construction project in accordance with client's objectives. Isa et al., [3] have highlighted that; managing construction projects with less spirit of leadership can weaken the organization in its ability to deal with challenges. Moreover, Toor \& Ogunlana [4] outlined several issues of leadership in the construction

\footnotetext{
${ }^{*}$ Corresponding author : $\underline{\text { df080116@gmail.com }}$
} 
industry such as poor communication, lack of experience and lack of planning. These issues make construction leaders appear incompetent and ineffective in the workplace. A study carried out by Nauman \& Khan [5] found that positive leadership has contributed almost $76 \%$ to the success of project. Hence, the need of a good leader with good leadership qualities is crucial to steer construction project successfully. An outstanding leader should possess good leadership qualities as problem solver, communicator and motivator in the organization [6]. Thus, this study considers project managers, construction managers, construction chiefs and project site supervisors are the targeted construction leaders. And it uncovered the important leadership qualities required by construction leaders from the perspective of construction experts in Makkah city.

\section{Literature Review}

To success in construction industry, it needs a professional with good quality management and leadership skills more than technical skills [7]. Nevertheless, experience and technical background are also important in engineering and construction field but still the critical skills for construction leaders are leadership and managerial skills [8]. According to Benator \& Thumann [2], leadership and management skills can help the project manager to achieve the project objectives. There are many studies on leadership qualities and a comprehensive reviewed on these studies had resulted of identifying 26 common leadership qualities as in table 1.

Table 1. Leadership qualities from previous studies.

\begin{tabular}{|l|l|}
\hline \multicolumn{1}{|c|}{ Qualities } & \multicolumn{1}{|c|}{ Sources/References } \\
\hline Visionary & {$[6,8,9,10,11,12,13,14,15,16,17,18,19,20,21]$} \\
\hline Effective Planning and Goal Setting & {$[8,9,11,22,17,23,24,25]$} \\
\hline Critical Analysis skills & {$[14,15,18,20,21]$} \\
\hline Problem Solver & {$[6,8,14,17,20,22,24,26,27,28]$} \\
\hline Technical ability & {$[12,16,17,19,29]$} \\
\hline Initiative of doing things & {$[8,15,16,18,18,26]$} \\
\hline Create strategies & {$[14,15,20,21]$} \\
\hline Team building skills & {$[5,8,9,13,23,24,30]$} \\
\hline Decision making skills & {$[5,6,16,17,19,22,24,25,27,28,30]$} \\
\hline Sense of responsibility & {$[8,11,16,19,23,24,28,29]$} \\
\hline Empowerment & {$[6,9,12,13,14,15,18,20,21,23,25,30]$} \\
\hline Monitor results & {$[5,6,8,14,20,23]$} \\
\hline Integrity & {$[10,12,16]$} \\
\hline Honesty and trustworthy & {$[6,12,16,19,23,25,29]$} \\
\hline Equity & {$[11,13,16,19]$} \\
\hline Effective communication & {$[5,6,8,9,10,12,13,14,15,17,18,20,21,22,24,25,26,27,28,29,30]$} \\
\hline Time management skills & {$[5,6,8,13,24,25]$} \\
\hline Effective resource management & {$[12,14,15,18,20,21]$} \\
\hline Resolving conflict & {$[5,8,13,22,24]$} \\
\hline Networking skills & {$[11,17,18,29]$} \\
\hline Ethical behaviour & {$[8,12,19,30]$} \\
\hline Influencing skills & {$[8,9,12,14,15,18,2022,29]$} \\
\hline Self-confidence & {$[17,26,29]$} \\
\hline Negotiator & {$[11,17,23,26,27]$} \\
\hline Good Motivator & {$[6,11,12,14,15,18,20,23,27]$} \\
\hline Delegator & {$[5,6,12,28]$} \\
\hline &
\end{tabular}


The qualities in table 1 together with 28 qualities attained from qualitative exploratory study were used in questionnaire design to uncover the important leadership qualities for Makkah's construction industry. These 54 qualities are classified into 4 clusters namely Problem Solving and Decision-Making Capacity (PSDMC), Achievement Appetite and Delivery Capacity (AADC), Relationship Building and Influencing Capacity (RBIC) and Risk Taking and Strategic Change Capacity (RTSCC).

\section{Data Collection}

Questionnaire survey was conducted to uncover the perception of Makkah's construction experts towards the important leadership qualities that should be possessed by construction leaders. Data was collected using semi-structured questionnaire survey. The questionnaire was designed based on literature review and also the outcomes of qualitative exploratory study. Experts were requested to indicate the level of significance on the identified 54 leadership qualities using 5-point Likert's significance scale which is $1=$ not significant, $2=$ slightly significant, $3=$ moderately significant, $4=$ significant and $5=$ very significant [31]. The questionnaire was distributed to the targeted construction experts who have more than 10 years of working experiences from contractor's organizations through site visit and managed to secure 31 valid responses. Demography of the experts involved in this study is presented as in figure 1.

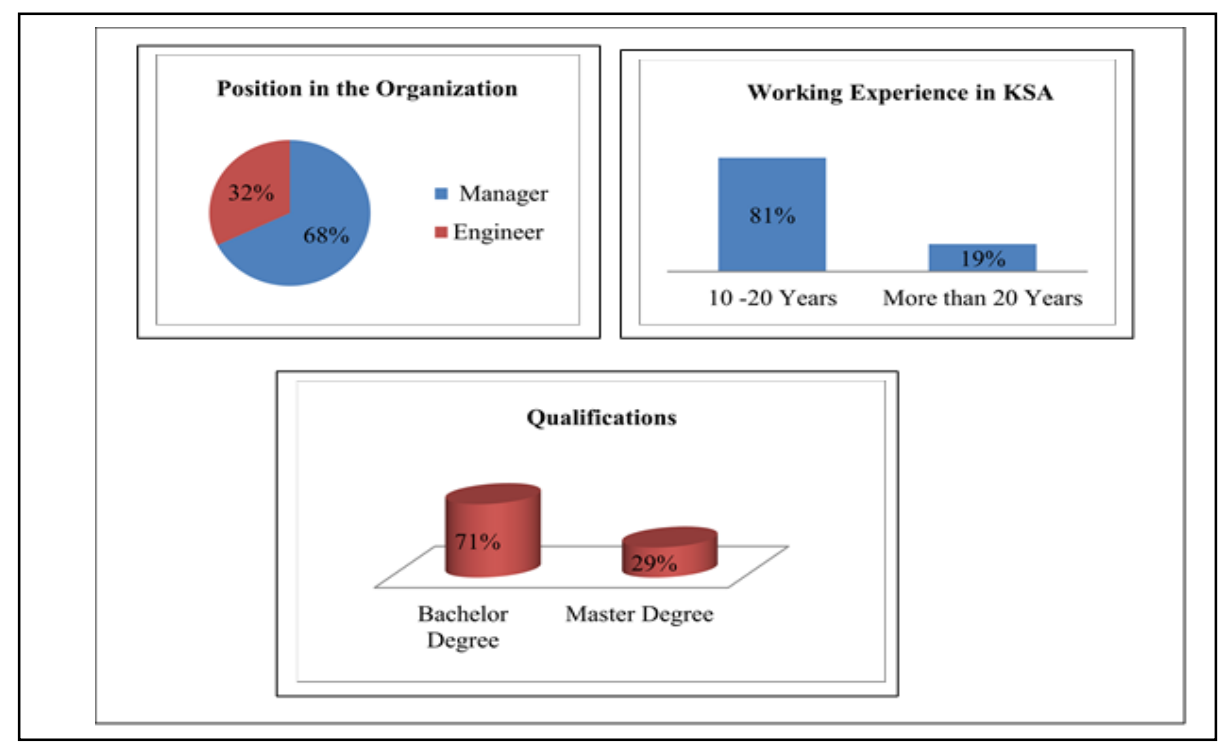

Fig. 1. Experts' Demography.

It can be perceived from figure 1 that $32 \%$ of the experts are holding managerial designations in their organizations and having more than 10 years of working experience in the Saudi's construction industry. The experts hold academic qualifications either bachelor or master degree. Hence, it indicates that the selected experts are eligible and competent in giving their opinions regarding the leadership qualities required by construction leaders for the Makkah's construction industry. 


\section{Data Analysis and Results}

Before the collected data can be analysed, the data needs to be checked on its stability and consistency using Cronbach's alpha value of reliability test. The Cronbach $\alpha$ value is widely adopted to measure the inner consistency of the data [32]. The degree of consistency varies with Cronbach's alpha value is between 0 and 1 , where the higher values reflect a higher degree of internal consistency of the data [33]. According to Li and Wang [34], if Cronbach alpha value is less than 0.3, the reliability is considered low and data cannot be accepted and if the Cronbach alpha value is more than 0.7 , it indicates consistency of data is high and acceptable [35]. However, the calculated Cronbach's alpha coefficients for this study are shown as in table 2 .

Table 2. Reliability test results.

\begin{tabular}{|l|c|c|}
\hline \multicolumn{1}{|c|}{ Leadership Quality's Group } & $\begin{array}{c}\text { Number of } \\
\text { quality's items }\end{array}$ & $\begin{array}{c}\text { Cronbach's } \\
\text { Alpha }\end{array}$ \\
\hline Problem Solving and Decision-Making Capacity (PSDMC) & 14 & 0.836 \\
\hline Achievement Appetite and Delivery Capacity (AADC) & 12 & 0.919 \\
\hline Relationship Building and Influencing Capacity (RBIC) & 16 & 0.948 \\
\hline Risk Taking and Strategic Change Capacity (RTSCC) & 12 & 0.848 \\
\hline \multicolumn{2}{|c|}{ Overall Average } & 0.888 \\
\hline
\end{tabular}

Cronbach's alpha values for each group and the overall data are higher than 0.7 as shown in table 2 . This indicates that the collected data for this study is considered highly valid and reliable to carry out the further analysis.

\subsection{Significant Leadership Qualities}

In the second part of the questionnaire form, experts were required to rate each of the 54 leadership qualities using 5-points Likert's scale. The data from this part is analysed using Average Index method (AI) to determine each of the quality's level of significant in dealing with construction workers [36]. However, to decide which qualities are significant, then quality having average index score higher than the mean of total average index score of the qualities is considered as threshold value. In this case, the mean of total average index score of the qualities is 4.16 and the significant qualities which are equal or above of this threshold value are as in table 3 .

Table 3. Significant leadership qualities.

\begin{tabular}{|c|l|c|c|}
\hline Group & Leadership Quality & AI Score & Rank \\
\hline RTSCC & Self-confident & 4.45 & 1 \\
\hline PSDMC & Problem solving skills & 4.39 & 2 \\
\hline AADC & Willingness to take responsibility & 4.32 & 3 \\
\hline AADC & Honest and trustworthy & 4.29 & 4 \\
\hline AADC & Respectful with subordinates & 4.29 & 5 \\
\hline RTSCC & Sufficient experience & 4.26 & 6 \\
\hline AADC & Integrity & 4.23 & 7 \\
\hline RBIC & Effective management skills & 4.23 & 8 \\
\hline RTSCC & Continuous quality improvement & 4.19 & 9 \\
\hline AADC & Reliable with subordinates & 4.16 & 10 \\
\hline
\end{tabular}


Table 3 indicates that self-confident is the most significant quality that should be possessed by construction leaders while the second quality is problem solving, the third is taking responsibility, the fourth is honest and trustworthy, and the fifth is respectful with subordinates. These five main qualities are further elaborated in accordance with the explanations given by the experts while conducting the semi-structured questionnaire survey.

\subsubsection{Self-confident}

According to the survey, self-confident is considered the most significant leadership quality for construction leaders in dealing with construction worker's issues. Selfconfidence is the ability of construction leader to be certain of his actions and behaviours during encountering problems especially with the workers at construction sites. It is an important quality that leaders should be equipped with in order to encourage themselves to take risk, achieve high targets and take immediate actions/decisions towards problems or conflict that may arise during construction activities.

\subsubsection{Problem solving skills}

Problem solving skills is the second important quality for construction leaders. It is crucial for construction leader to deal appropriately in resolving problems, how to identify the root cause of the problems, propose practical solutions, and to execute the solutions. In Saudi's construction projects, there are several issues faced by construction leaders such as financial issues, quality issues, safety issues, human resource issues and others. Thus, construction leaders should actively and properly act upon all these problems to ensure smooth running of construction projects.

\subsubsection{Willingness to take responsibility}

Leaders should have the willingness to take responsibility in order to take care of their employee's welfare and ensure that their salaries are regularly paid on-time even though during negative cash flow period to ensure a smooth running of the project tasks without disruptions. Also, construction leaders should act enthusiastically to manage and control any problem may occur at construction site. Furthermore, construction leaders should be responsible and have wills to lead construction project successfully within its budget, schedule, required quality and safety compliance.

\subsubsection{Honest and trustworthy}

Construction leaders should be honest and trustworthy in dealing with construction workers to ensure project success. Based on the experts' opinion, construction leader should show continuous honest actions with his subordinates/workers and he should establish a strong trust with them. Besides, construction leader should discuss openly and transparently all issues related to his subordinates and also, he should fulfil his promises and words. Also, the experts have appointed out that, the most essential elements for effective communication between manager and workers is the trust which can retain a good and strong relationship between them. If the honesty is shown and trust between manager and workers is established, then the performance and productivity of the workers will be at highest level for the benefit of the project. 


\subsubsection{Respectful with subordinates}

Respectful with subordinate's attributes is ranked as the fifth significant quality required for construction leaders. According to the experts' responses, it is vital for construction leaders to show continuous respects to their subordinates and treat them as human being regardless of their nationalities or positions. This behaviour shown by leaders, it will make subordinates less stressful, feeling in more friendly and less threatening working environment. Once the respect to leaders are established and continuously maintained, the productivity from subordinates/workers will increase and ensure completion of a project timely.

\section{Conclusion}

The success of construction projects largely depends on the construction leader's performance. Thus, construction leader should be equipped with wide variety of leadership qualities and experiences to steer construction projects successfully. This study has uncovered the important leadership qualities that should be possessed by construction leaders in handling workers issues for Makkah's construction industry. Based on the analysis results, 10 significant leadership qualities are identified including self-confident, problem solving skills, willingness to take responsibility, honest and trustworthy, respectful with subordinates, sufficient experience, integrity, effective management skills, continuous quality improvement and reliable with subordinates. These findings are considered valuable contributions to construction practitioners of Makkah city and to entire kingdom of Saudi Arabia for identifying potential leaders to carry out their construction projects effectively and efficiently.

\section{Acknowledgement}

The authors would like to thank and acknowledge Universiti Tun Hussein Onn Malaysia (UTHM) for the financial support using the grant name "Contract Grant A074 Renalcare Research Fund". Also, the authors would like to thank and appreciate the construction experts for their significant contributions to this research.

\section{References}

[1] G. Ofori, S. U. R. Toor. Leadership and Construction Industry Development in Developing Countries. Journal of Construction in Developing Countries, 17 (2012)

[2] B. Benator, A. Thumann. Project Management \&Leadership Skills for Engineering \& Construction Projects, CRC Press.Unites States, (2003)

[3] C. M. M. Isa, H. M. Saman, C. N. Preece. Determining Significant Factors Influencing Malaysian Construction Business Performance in International Markets. Journal of Construction in Developing Countries, 20 ,2, 1 (2015)

[4] S. U. R. Toor, S. Ogunlana. Ineffective leadership : Investigating the negative attributes of leaders and organizational neutralizers. Engineering, Construction and Architectural Management, 16 ,3, 254-272 (2009)

[5] S. Nauman, A. M. Khan. Patterns of leadership for effective project management. Journal of Quality and Technology Management, 20 (2006)

[6] N. A. N. Nasaruddin, I. A. Rahman. Exploratory Study on Malaysia Construction Leadership. In MATEC Web of Conferences, 103, p. 03005). EDP Sciences (2017) 
[7] G. Ofori. Leadership for future construction industry: Agenda for authentic leadership. International Journal of Project Management, 26,6, 620-630, (2008)

[8] G. H. Jarad. The construction manager leading characteristics for the success of construction projects in the Gaza Strip. The Islamic university of Gaza: M.Sc. Thesis, (2012)

[9] V. K. Verma, R. M. Wideman. Project Manager to Project Leader, (1994)

[10] R. Tait. The attributes of leadership. Leadership \& Organization Development Journal, 17,1, 27-31, (1996).

[11] I. A. Abdalla, M. A. Al-Homoud. Exploring the implicit leadership theory in the Arabian Gulf states. Applied Psychology, Balckwell Publisher 50,4, 506-531, (2001)

[12] R. F. Russell, A. Gregory Stone. A review of servant leadership attributes: Developing a practical model. Leadership \& Organization Development Journal, 23,3, 145-157, (2002)

[13] T. H. Hopkins. Ten essential leadership skills for managers, (2009), $<$ file://C:/Users/Nashwan/Downloads/Ten\%20Essential\%20Skills\%20for\%20Manage rs.pdf $>$

[14] R. Müller, R. Turner, R. Leadership competency profiles of successful project managers. International Journal of Project Management, 28,5, 437-448, (2010)

[15] R. Müller, J. Rodney Turner. Attitudes and leadership competences for project success. Baltic Journal of Management, 5,3, 307-329, (2010)

[16] M. Bernard. Capabilities of Effective Engineering Leaders, (2011), $<$ https://gelp.mit.edu/sites/default/files/documents/leadershipcapabilities.pdf $>$

[17] P. P. Bhangale, R. Devalkar. Study the Importance of Leadership in Construction Projects, IJLTET,2,3, (2013)

[18] J. Meng, B. Xue, B. Liu, N. Fang. Relationships between top managers' leadership and infrastructure sustainability: A Chinese urbanization perspective, Engineering, Construction and Architectural Management, 22,6, 692-714, (2015)

[19] R. Paul, L. C. Falls. Comparison of Career Success Competencies and Engineering Leadership Capabilities. Proceedings of the Canadian Engineering Education Association, (2015)

[20] E. Elfwering, J. Sæmundsdóttir. Leadership Competencies as Success Factors for Project Performance. Chalmers University of Technology: M.Sc Thesis, (2016)

[21] A. A. Tabassi, M. Argyropoulou, K. M. Roufechaei, R. Argyropoulou. Leadership Behavior of Project Managers in Sustainable Construction Projects. Procedia Computer Science, 100, 724-730, (2016)

[22] S. D. Anderson. Project quality and project managers. Int. J. Project Management, 10 3, 138-144, (1992)

[23] C. F. Gomes, M. M. Yasin. Managing Public Sector Projects in Portugal: Meeting the Challenge Through Effective Leadership. Journal of Leadership, Accountability and Ethics, 10,2, 113-122, (2013)

[24] I. B. Bt Zakaria, M. R. B. Mohamed, N. bt Ahzahar S. Z. bt Hashim. A study on Leadership Skills of Project Manager for a Successful Construction Project. International Academic Research Journal of Social Science 1(2), 89-94, (2015)

[25] N. A. N. Nasaruddin, I. A. Rahman. Leadership Quality for Malaysia Construction Leader to Steer a Success Construction Project. In MATEC Web of Conferences, 47, EDP Sciences, (2016) 
[26] J. R. Turner, The handbook of Project-Based Management : improving the processes for achieving strategic objectives. London, UK: Mcgraw-Hill, (1999)

[27] K. T. Odusami. Perceptions of construction professionals concerning important skills of effective project leaders. Journal of Management in Engineering, 18,2, 61-6, (2002)

[28] S. U. R. Toor, S. O. Ogunlana. Leadership skills and competencies for cross-cultural construction projects. International Journal of Human Resources Development and Management, 8,3, 192-215, (2008)

[29] R. Bolden, B. Hawkins, J. Gosling, S. Taylor. Exploring leadership: Individual, organizational, and societal perspectives. OUP Oxford, (2011)

[30] J. v. Farr, S. G. Walesh, G. B. Forsythe. Leadership development for engineering managers. Journal of Management in Engineering, 13,4, 38-41, (1997)

[31] N. Al-Emad, I. A. Rahman, S. Nagapan Y. Gamil. Ranking of delay factors for Makkah's construction industry. In MATEC Web of Conferences, 103, p. 03001). EDP Sciences, (2017)

[32] N. Al-Emad. Structural relationships model of delay factors in Makkah construction industry (Master dissertation, Universiti Tun Hussein Onn Malaysia, (2016)

[33] U. Sekaran, R. Bougie. Research Methods for Business: A Skill Building Approach. London: Wiley, (2010)

[34] X. Li, R.Wang. Survey Research on Relationship among Service Failure: Service Recovery and Customer Satisfaction. Proceedings of the International conference on Management Science and Engineering, Harbin, China. pp. 1121-1123, (2007)

[35] J. Pallant. SPSS Survival Manual: A Step by Step Guide to Data Analysis Using SPSS for Program. (4th ed.). Australia, Allen \& Unwin, (2011)

[36] N. H. Al-Emad, S. Nagapan. Identification of delay factors from Mecca's construction experts perspective. International Journal of Sustainable Construction Engineering and Technology, 6,2, 16-25, (2015) 